\title{
Improving EFL Learners' Pronunciation of English through Quiz-Demonstration-Practice-Revision (QDPR)
}

\author{
Moedjito \\ ${ }^{1}$ Department of English Language Education, Hamzanwadi University, Lombok Timur, Indonesia \\ Correspondence: Moedjito, Department of English Language Education, Hamzanwadi University, \\ LombokTimur, Indonesia. Tel: 62-0877-6304-2448. E-mail: mas.moedjito@gmail.com
}

\author{
Received: October 23, 2017 Accepted: December 1, 2017 Online Published: December 2, 2017 \\ doi: $10.5539 /$ elt.v11n1p10 URL: http://doi.org/10.5539/elt.v11n1p10
}

\begin{abstract}
This study investigates the effectiveness of Quiz-Demonstration-Practice-Revision (QDPR) in improving EFL learners' pronunciation of English. To achieve the goal, the present researcher conducted a one-group pretest-posttest design. The experimental group was selected using a random sampling technique with consideration of the inclusion criteria. Through the treatment process, the group was taught using QDPR in which the student participants were explained how to pronounce the target English phonemes in their first language (L1). The student participants were given an oral test and a written test related to the target English phonemes and a questionnaire on QDPR. The collected data were analyzed using paired-sample t-tests to examine the significant difference in the means scores of their knowledge of pronunciation and their ability to pronounce the target English phonemes, and simple regression tests to investigate the effectiveness of QDPR learning model to their knowledge of pronunciation and their ability to produce the target phonemes. The results of data analysis have revealed that (1) QDPR was significantly effective in improving EFL learners' pronunciation, and (2) QDPR significantly helped the students improve their pronunciation. Thus, QDPR can be an alternative model to English pronunciation instruction in EFL classrooms.
\end{abstract}

Keywords: intelligibility, pronunciation teaching, Quiz-Demonstration-Practice-Revision (QDPR)

\section{Introduction}

The nature of language as a system implies that a language is composed of two systems: a system of sounds and a system of meaning. The relationship between those two systems is very important because in human verbal communication meaning or message is conveyed or received primarily through sounds or vocal symbols. These vocal symbols are expressed in the form of words (vocabulary) and arranged in certain grammatical structures (grammar). In terms of oral language, there must be message (meaning), grammar, vocabulary and pronunciation. Additionally, another feature of human communication is that language is a cultural transmission. It denotes that a communication system must be discovered through communicative interaction with other users of the language. This suggests that not only features of a language can be totally acquired, but also some parts of the language should be learnt. Thus, language learning is also needed.

The consequence of both features of human language above is that in any language programs, including English language education, pronunciation as a part of system of sounds should be propositionally treated as two other dominant components of language, namely grammar and vocabulary. However, the current situation, particularly English language in Indonesia, shows that most people who are involved directly or indirectly in English language teaching and learning programs only concentrate on their attention to the last two components. This situation actually contrasts with the nature of language itself which requires a balanced deal of language system and meaning (Tudor, 2001). We shall, therefore, include pronunciation as a part of our language teaching programs because paying no or less attention to pronunciation teaching does eventually affect students' language mastery and the process of the whole communication, particularly when Indonesian EFL learners utilize the target language in real situations later. At the beginning level, the insufficient capability of pronunciation, of course, does not always have a significant impact on the process of communication but at higher levels of oral communication it does.

The reappraisal of pronunciation teaching in EFL contexts is also in line with the globalization which increases the role and status of English. Nowadays, English really becomes a global language. English is one of the main 
languages for oral communication (Crystal, 1997; Jenkins, 2000; McKay, 2002). A pedagogical implication of the status of English as a global language, we need to reappraise pronunciation as a part of English teaching in EFL classrooms (Jenkins, 2000; McKay, 2002, Moedjito, 2006). In the process of re-examination of pronunciation teaching, as Cruttenden (2001) reminds us, we need to answer the following three questions:

(1) What form of pronunciation is to be taken as a model?

(2) What level of performance is to be aimed at?

(3) What general principles should underlie the teaching of pronunciation?

The first question is the most crucial because we start teaching pronunciation from this point. In earlier days, the answer may be simply the undifferentiated British English or American English. However, native accents of English are not only Received Pronunciation and General American English. We still have some other accents such as English spoken in Australia, New Zealand, and South Africa. But now, as an impact of globalization, it is more difficult to provide an appropriate answer to the question because there are also foreign language varieties such as Japanese English (Japlish), Singaporean English (Singlish), and many others. The more appropriate answer to the question may be English spoken by many people in the globe, either as a working language or as a daily life language. However, which model of pronunciation is still unclear. For this reason, it is necessary to address which type of English is appropriate as a model of pronunciation teaching in EFL classrooms. According to von Schon (1987), there are four criteria for choosing a model for pronunciation teaching: (1) a model of English which is most admired in our own region, (2) a model of English which is most useful for our students, (3) a model of English which is the most consonant with the attitude of our school administration, and (4) the availability of teaching materials such as textbooks, tapes, and others. As a concluding remark, von Schon strongly recommends that some standard from near top of the cline should be considered; for example, Japanese English in Japan or Indonesian English in Indonesia. However, it is also difficult to find the standard for these models. Alternatively, Cruttenden (2001) proposes the following step: as for the beginners it is better for us to introduce a British spoken form; when this production habit is firmly established, then we exposed our students to General American English or other varieties of English.

In terms of the second question, traditionally the goal of pronunciation teaching has been to enable EFL learners to attain native-like pronunciation of English. However, as more and more people have come to use English as a means of wider communication across cultures, the focus of pronunciation teaching has shifted from how EFL learners can attain native-like pronunciation to how they can transact information effectively in oral communication. As a result, intelligibility rather than native-like pronunciation has become a legitimate goal of pronunciation teaching (Abercrombie, 1963; Celce-Murcia, Brinton, \& Goodwin, 1996; Jenkins, 2000). This leads us to another crucial question in pronunciation teaching: What aspects of pronunciation constitute intelligibility? It is not so simple a question to answer since intelligibility is generally divided into three types: comfortable intelligibility (i.e., intelligibility which non-native speakers should aim at when they try to talk to native speakers), mutual intelligibility (i.e., intelligibility which non-native speakers should aim at when they try to talk to non-native speakers), and global intelligibility (i.e., intelligibility which non-native speakers should aim at when they try to talk not only to native speakers but also to non-native speakers). Comfortable intelligibility is usually achieved by a successful manipulation of rhythm, intonation, and word and sentence stresses (Celce-Murcia et al., 1996; Cruttenden, 2001) while mutual intelligibility is usually achieved by a successful manipulation of segmental features (consonants and vowels) and sentence stress (Jenkins, 2000). Global intelligibility (Moedjito \& Ito, 2008) is usually achieved by a successful manipulation of segmental accuracy, word stress, nuclear stress, and adjustments in connected speech.

The third question deal with the priority and techniques for teaching pronunciation. In terms of priority of pronunciation instruction, a survey conducted by Moedjito (2008) indicated that both Indonesian secondary school teachers and students perceived that both consonants and vowels were still the most preferable components to teach/learn rather than the others whereas phonetic transcription and rhythm should not be the main priority. The finding of the survey is supported by Moedjito's study (2016) which revealed the importance of segmental features of English pronunciation. Surprisingly, this finding is not in accordance with the 1990s trend of pronunciation teaching which strongly recommends suprasegmental features (Bowen, Madsen, \& Hilferty, 1985; Florez, 1998; Wong, 1987). Florez (1998) urges that suprasegmental features are assumed to be more prominent in pronunciation instruction. Wong (1987) also claims that the most relevant components of pronunciation which play a greater role in English communication are stress, rhythm, and intonation. However, Bowen, Madsen, and Hilferty (1985) suggest a sequence built on fluency, stress, rhythm and intonation, and vowels and consonants. Thus, although the current trend of pronunciation teaching is on suprasegmental features, 
the survey showed that segmental features should be regarded as more important for Indonesian EFL learners. As the techniques for teaching pronunciation is concerned, the latest study (Moedjito, 2016) has unveiled that EFL teachers should utilize a variety of techniques for teaching pronunciation as proposed by some applied linguists such as Celce-Murcia et al. (1996), Dalton and Seidlhofer (1994), Jennner (1989), Kelly (2000), and Tudor (2001). For instance, Tudor (2001) claims that clear explanation of pronunciation and intonation can call the use of (IPA-based) phonetic transcription which can increase the total learning load of students. However, there is one important technique found in the study, namely teacher explanation in students' L1. This point becomes a main difference from other applied linguists. Teacher explanation in students' own language makes them easier to understand the procedural knowledge of language, particularly the system of English phonology.

Based on the above discussion, it is necessary for us to adopt a learning model of pronunciation teaching that is suitable for our goal, that is, global intelligibility (Moedjito \& Ito, 2008). Regarding the priority and techniques for teaching pronunciation in EFL classrooms (Celce-Murcia et al., 1996; Dalton \& Seidlhofer, 1994; Moedjito, 2016), the present researcher proposed a learning model in pronunciation teaching, namely Quiz-Demonstration-Practice-Revision (QDPR). Basically, the overall step of QDPR is similar to the step of common language learning, especially related to pre-activity, whilst-activity, and post-activity. However, compared with other models of pronunciation teaching, QDPR has distinctive steps, particularly in whilst-activity. As its name, there are four prominent steps of QDPR briefly described in Table 1.

QDPR learning model of pronunciation began with Quiz. In this step, the teacher started with asking the students to pronounce the target phonemes on the shown flashcards. He/she asked the students individually, in group, or classically. While asking the students to produce the target phonemes, he/she paid attention to the target phonemes produced by the students. In this way, he/she would decide whether the students produced the target phonemes accurately or not. Thus, he/she could decide if all the students or some of them had difficulties in producing the target phonemes. Whenever he/she found that the students, even only one student, had problems with pronunciation, he/she could proceed to the next step.

Having identified the students' difficulties in pronouncing the target phonemes, the teacher continued the learning process to the second step, namely Demonstration. First, he/she explained how to produce the target phonemes in students' first language (L1), in this case Bahasa Indonesia. The medium of teachers' explanation in Bahasa Indonesia was the most prominent characteristic of QDPR learning model. The objective of using students' L1 is to make easier the students understand how to produce the target phonemes. Secondly, as the name of this step, he/she demonstrated how to produce the target phonemes. These two steps had to be done simultaneously so that not only did the students understand how to produce the target phonemes, but also they are able to produce them. By doing so, in the second step, the students were introduced to some knowledge of English pronunciation and encouraged to produce accurately the target phonemes. This step ended with his/her confirmation on students' understanding of how to produce the target phonemes. Whenever there was a positive confirmation from the students, the next step, namely Practice, could be done.

By dividing the students into several small groups, the step of Practice began with providing an opportunity for the students to analysis and to identify the target phonemes with their spelling. This step should be done because English is one of deep languages, meaning that the spellings do not correlate to their sounds: different spellings make the same sounds, the same spellings make different sounds. That is why it is crucial to do spellings-sounds analysis and identification. Following this step, the students were given a chance to do oral practices. The oral practice may be done individually, in group, or classically. The aim of this step is to provide the students with ample time to recognize and to produce the target phonemes. While the students were practicing orally the target phonemes, the teacher was identifying students' potential problems. Whenever he/she found the problems, both students and the teacher were at the step of Revision.

As explained above, the step of Revision occurred because of the identified problems faced by the students the step of Practice. This step can be done individually, in group, or classically, depending on how many students had problems. One or two students would be treated individually, some students would be treated in group, and most of the students would be classically revised. However, in some cases, the teacher could not detect the students' problems in oral practices. If this situation happened, the teacher provided some time to the students to ask questions or to give comments on that day's teaching and learning process. If so, he/she might ask other students to answer or give comments on their friends' questions/comments. 
Table 1. The characteristics of Quiz-Demonstration-Practice-Revision (QDPR) learning model

\begin{tabular}{|c|c|c|c|}
\hline \multirow{2}{*}{ Steps of QDPR } & \multicolumn{2}{|l|}{ Main Activities } & \multirow{2}{*}{$\begin{array}{l}\text { Recommended } \\
\text { Teaching Media }\end{array}$} \\
\hline & Teacher & Students & \\
\hline $\begin{array}{l}\text { 1) } \\
\text { Quiz }\end{array}$ & $\begin{array}{l}\text { - Giving a quiz to students by } \\
\text { showing the flashcards of the } \\
\text { target English phonemes. The } \\
\text { quiz can be done individually, in } \\
\text { group or classically. } \\
\text { - Identifying students' } \\
\text { problems. }\end{array}$ & $\begin{array}{l}\text { - Pronouncing the target } \\
\text { English phonemes individually, } \\
\text { in group or classically. }\end{array}$ & $\begin{array}{l}\text { - Flashcards } \\
\text { of the target } \\
\text { phonemes }\end{array}$ \\
\hline $\begin{array}{l}\text { 2) } \\
\text { Demonstration }\end{array}$ & $\begin{array}{l}\text { - Explaining how to produce } \\
\text { the target English phonemes in } \\
\text { the students' mother tongue (L1) } \\
\text { or the language the students are } \\
\text { familiar with. } \\
\text { - Demonstrating how to } \\
\text { produce the target English } \\
\text { phonemes. }\end{array}$ & $\begin{array}{l}\text { - Observing the } \\
\text { demonstration of the target } \\
\text { sound production performed by } \\
\text { the teacher. } \\
\text { - Producing the target } \\
\text { English phonemes. }\end{array}$ & $\begin{array}{l}\text { - Flashcards } \\
\text { of the target } \\
\text { English } \\
\text { phonemes } \\
\text { - Laptop } \\
\text { - LCD } \\
\text { Projector }\end{array}$ \\
\hline $\begin{array}{l}\text { 3) } \\
\text { Practice }\end{array}$ & $\begin{array}{l}\text { - Dividing the class into } \\
\text { several small groups. } \\
\text { - Asking the groups to analyse } \\
\text { the corresponding letters to the } \\
\text { target English phonemes. } \\
\text { - Asking the groups to } \\
\text { presents the results of the group } \\
\text { discussion. } \\
\text { - Asking the students to do } \\
\text { oral practices of the target English } \\
\text { phonemes individually, in group, } \\
\text { or classically. } \\
\text { - Identifying the students, } \\
\text { problems. }\end{array}$ & $\begin{array}{l}\text { - Dividing themselves in } \\
\text { small groups. } \\
\text { - Analysing } \\
\text { corresponding letters to the } \\
\text { target English phonemes. } \\
\text { - Presenting the results of the } \\
\text { group discussion. } \\
\text { - Doing oral practices of the } \\
\text { target English phonemes } \\
\text { individually, in group, or } \\
\text { classically. }\end{array}$ & $\begin{array}{l}\text { - Student } \\
\text { Worksheet } \\
\text { - Flashcards } \\
\text { of the target } \\
\text { English } \\
\text { phonemes } \\
\text { - Laptop } \\
\text { - LCD } \\
\text { Projector }\end{array}$ \\
\hline $\begin{array}{l}\text { 4) } \\
\text { Revision }\end{array}$ & $\begin{array}{l}\text { - Discussing the students' } \\
\text { problems based on the problem } \\
\text { identification. } \\
\text { - Revising the students, } \\
\text { mistakes of the target English } \\
\text { phonemes individually, in group, } \\
\text { or classically. }\end{array}$ & $\begin{array}{l}\text { - Discussing the students' } \\
\text { problems based on the problem } \\
\text { identification. } \\
\text { - Practicing the target } \\
\text { English phonemes. }\end{array}$ & $\begin{array}{l}\text { - } \quad \text { Student } \\
\text { Worksheet } \\
\text { - } \quad \text { Flashcards } \\
\text { the target English } \\
\text { phonemes } \\
\text { - Laptop } \\
\text { - LCD } \\
\text { Projector }\end{array}$ \\
\hline
\end{tabular}

However, we do not have any information if QDPR is significantly effective as learning model in pronunciation teaching. We do not know if QDPR can improve EFL learners' knowledge of English pronunciation. Finally, we do not know of QDPR can improve EFL learners' oral performance. Thus we really need this information so that QDPR may become an alternative learning model in pronunciation teaching. To provide this missing information, the current researcher tried to examine the effectiveness of QDPR in improving university students' knowledge 
of the target English phonemes and their ability to pronounce these phonemes. To be more specific, the present researcher intentionally chose some English phonemes which were identified as serious and common

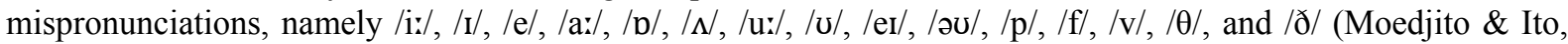
2008). The details of the investigated English phonemes are presented in Table 2. The current research was aimed at answering the following research questions:

(1) Is QDPR significantly effective in improving EFL learners' knowledge of the target English phonemes?

(2) Is QDPR significantly effective in improving EFL learners' ability to produce the target English phonemes?

(3) How does QDPR contribute to EFL learners' knowledge of the target English phonemes?

(4) How does QDPR contribute to EFL learners' ability to pronounce the target English phonemes?

\section{Method}

\subsection{Participants}

Forty-two Indonesian university students were involved in the present study, comprising of 31 students served as the student participants and 11 students served as the student teachers. They were enrolling Department of English Language Education at a private university in the regency of Lombok Timur, the province of Nusa Tenggara Barat, Indonesia. In the teaching and learning process, the student participants were taught by the student teachers using QDPR learning model. The student participants of the study were selected regarding the following inclusion criteria: (1) they were at the second semester and had attended the course of English Pronunciation Practice offered by the Department of English Language Education, Hamzanwadi University at the first semester, (2) they still had difficulties in English vowels and consonants based on the results of the diagnostic test of English pronunciation, and (3) they participated voluntarily in the study which was designed for 11 sessions (by signing a Letter of Consent). Thus, if a participant was absent for one session or more, they would be excluded. Meanwhile, the student teachers were at the eighth semester and selected on the basis of their interest in the study of English pronunciation as the main topic of their undergraduate thesis. In general, they had much better understanding of English pronunciation than the student participants. Prior to the implementation of QDPR learning model, the student teachers had to attend an upgrading class for Pronunciation Instruction through QDPR. In addition to the participants, the present study involved two senior lectures of English as a foreign language (EFL) as the assessors of the student participants' oral performance.

\subsection{Data Collection}

To solve the proposed research questions, the data of the study was collected by three main different instruments: a questionnaire on QDPR learning model, an oral reading test, and a paper-and-pencil pronunciation test. The questionnaire was distributed to the student participants to provide information on their responses on QDPR learning model. The oral reading test was administered to measure the student participants' oral performance. Finally, the paper-and-pencil pronunciation test was administered to assess their knowledge of English target phonemes, as shown in Table 2.

The questionnaire on QDPR was developed on the basis of the proposed research questions and a number of considerations, such as the theories of language and language learning, numerous previous research findings (Moedjito \& Ito, 2008; Moedjito, 2016), the results of observations, and the author's self-experience as a senior lecturer at Department of English Language Education, Hamzanwadi University. The questionnaire was developed to discover the student participants' perceptions of implementation of QDPR learning model, including the participants' difficulty in pronunciation, the student participants' involvement in QDPR program, steps of QDPR learning model, teaching media, the allotted time for QDPR learning model, and the participants' general perceptions of QDPR learning model. The student participants were required to report their level of pronunciation by choosing one of the provided responses using 5-point Likert scale.

In terms of oral reading test, the student participants were asked to read aloud a 405-word passage (Appendix A). Their utterances were recorded and then presented to the assessors. For the statistical analysis, we focused on the first 20 speech sounds of the content words (tokens, not index) for each target English phoneme. The assessors gave a score for each utterance using 3-point Likert scale (i.e. $3=$ accurate, $2=$ not so accurate, and $1=$ not accurate). The accuracy level was on the basis of the Third Edition Cambridge Advanced Learner's Dictionary.

Concerning the paper-and-pencil pronunciation test, the student participants were required to complete the word-level pronunciation knowledge test, consisting of 100 questions for sound discrimination (Appendix B). Each question had four items. They were asked to examine if the underlined parts had the same pronunciation or not. They were asked to write ' 1 ' (one) in the provided space; otherwise, they had to write ' 0 ' (zero). The 400 
words in the test were basically selected from the word lists of Moedjito's book (in press) entitled English Pronunciation Practice. In order to elicit their real time judgment as much as possible, the student participants were required to spend only 25 seconds for each question.

Table 2. The investigated English phonemes

\begin{tabular}{|c|c|c|c|c|}
\hline \multirow{2}{*}{ No } & \multirow{2}{*}{$\begin{array}{l}\text { IPA* } \\
\text { Symbol }\end{array}$} & \multirow{2}{*}{ Name of Phonemes } & \multicolumn{2}{|l|}{ Examples } \\
\hline & & & In Words & In IPA \\
\hline 01 & $/ \mathrm{i} /$ & Unrounded close front vowel & creep; seat & /kri:p/; /si:t/ \\
\hline 02 & $/ \mathrm{I} /$ & Unrounded close-mid near-front vowel & mix; sit & $/ \mathrm{mrks} / ;$ /sit/ \\
\hline 03 & $/ \mathrm{e} /$ & Unrounded close-mid vowel & edge; set & /edz/; /set/ \\
\hline 04 & /a:/ & Unrounded open near-back vowel & car; part & /ka:/; /part/ \\
\hline 05 & $/ \mathrm{p} /$ & Rounded near-open back vowel & hot; pot & $/ \mathrm{hpt} / ; / \mathrm{ppt} /$ \\
\hline 06 & $/ \mathrm{L} /$ & Unrounded near-open near-back vowel & cut; shut & $/ \mathrm{k} \Lambda \mathrm{t} / ; / \int \Lambda \mathrm{t} /$ \\
\hline 07 & /ui:/ & Rounded close back vowel & cute; rude & /kju:t/;/ru:d/ \\
\hline 08 & $/ \mathrm{v} /$ & Rounded close-mid near-back vowel & book; should & /buk/;/fud/ \\
\hline 09 & /eI/ & Close-mid front close-mid near front closing diphthong & away; great & /ower/; /greit/ \\
\hline 10 & $/ \partial \mathrm{OU} /$ & Centre close-mid near-back closing diphthong & go; meadow & /gəu/;/medəu/ \\
\hline 11 & $/ \mathrm{p} /$ & Voiceless bilabial plosive consonant & pipe; pin & /parp/; /pin/ \\
\hline 12 & $/ \mathrm{f} /$ & Voiceless labiodental fricative consonant & five; fin & /faiv/; /fin/ \\
\hline 13 & $/ \mathrm{v} /$ & Voiced labiodental fricative consonant & vine; very & /vain/; /veri/ \\
\hline 14 & $/ \theta /$ & Voiceless dental fricative consonant & think; fifth & $/ \theta \mathrm{ink} / ; / \mathrm{fif} \theta /$ \\
\hline 15 & $/ / \mathrm{d} /$ & Voiced dental fricative consonant & father; with & /fa:ðə/; /wıð/ \\
\hline
\end{tabular}

Note: *International Phonetic Alphabet.

\subsection{Data Analysis}

The data collected from the questionnaire and tests were quantitatively analyzed. In addition to descriptive statistics, the data were submitted to paired-sample t-test to examine whether QDPR was significantly effective in improving EFL learners' knowledge of English target phonemes and their ability to produce them. Moreover, the Pearson's correlation coefficients were calculated for QDPR learning model to each dependent variables (i.e., EFL learners' knowledge of English pronunciation and their ability to pronounce English pronunciation of the target phonemes). If the coefficient of each correlation had at least a modest correlation $(r \geq .40)$, the data were then submitted to a simple regression analysis using IBM Statistics 22 for Windows.

\section{Results}

\subsection{Descriptive Statistics}

Table 3 depicts the summary of the descriptive statistics of the investigated variables in the current study, mean scores $(M)$, standard deviations $(S D)$, and the mean difference between pre- and post-tests. As shown in Table 3 , the mean scores in the pre-tests were 62.26 for EFL learners' knowledge of the target English phonemes, and 67.29 for EFL learners' ability to pronounce them. Meanwhile, the mean scores in the post-tests are 89.68 for QDPR learning model, 84.68 for EFL learners' knowledge of the target English phonemes, and 86.90 for EFL learners' ability to pronounce them. 
Table 3. Summary of descriptive statistics

\begin{tabular}{|c|c|c|c|c|c|}
\hline \multirow{2}{*}{ Investigated Variables } & \multicolumn{2}{|c|}{ Pre-Test } & \multicolumn{2}{|c|}{ Post-Test } & \multirow[t]{2}{*}{$t$ values } \\
\hline & $M$ & $S D$ & $M$ & $S D$ & \\
\hline QDPR Learning Model & & & 89.6 & 3.43 & \\
\hline EFL learner's knowledge of the target English phonemes & 62.2 & 4.80 & 84.6 & 5.41 & $22.07 * *$ \\
\hline EFL learners' ability to pronounce the target English phonemes & 67.2 & 3.86 & 86.9 & 4.41 & $44.17 * *$ \\
\hline
\end{tabular}

\subsection{The Effectiveness of QDPR Learning Model in Improving EFL Learners' Knowledge and Their Ability to Pronounce the Target English Phonemes}

A close examination of the differences in the mean scores between pre- and post-tests, as seen in Table 3 , we found that the differences between pre- and post-tests were quite high, 22.42 for EFL learner's knowledge of the target English phonemes and 19.61 for EFL learners' ability to pronounce the target English phonemes. After performing a series of paired-sample t-tests for the data of pretest and posttest, the results of data analysis have shown that there was a significant difference in the mean scores between the pre-test and the post for both of the investigated variables, $\mathrm{t}_{(\mathrm{df}=30)}=22.07$ at $p<.01$ and $\mathrm{t}_{(\mathrm{df}=30)}=44.17$ at $p<.01$ respectively. This implies that QDPR learning model is significantly effective in improving EFL learners' knowledge of the target English phonemes and EFL learners' ability to pronounce these phonemes. In short, QDPR might be an alternative learning model in pronunciation teaching in EFL classrooms.

\subsection{Contributions of QDPR to the Improvement of EFL Learners' Knowledge and Their Ability to Pronounce the Target English Phonemes}

Regarding the association between the independent variable and the dependent variables, the results of the study have indicated that the correlation coefficient between QDPR learning model and EFL learners' knowledge of the target English phonemes was .73 at $p<.01$ while the correlation between QDPR learning model and EFL learners' ability to pronounce the target English phonemes was .49 at $p<.01$. This implies that QDPR was significantly correlated to EFL learners' knowledge of the target English phonemes and their ability to pronounce the target English phonemes.

Although these correlation coefficients show the significant relationship between QDPR learning model to each dependent variables, they cannot tell us much about the predictive power of the independent variable, namely QDPR, to the dependent variables. In order to detect the causal-effect relationship between QDPR learning model and their dependent variables, simple regression tests were subsequently performed to each set of data. These simple regression tests could be done because the results of Pearson's correlation disclosed that both correlation coefficients were more than .40. The results of the simple regression analysis can be seen in Table 4 .

Table 4. Summary of simple regression analyses of QDPR learning model for the dependent variables

\begin{tabular}{lllll}
\hline Dependent Variables & B & SE B & $\beta$ & $R^{2}$ \\
\hline EFL learners' knowledge of English target phonemes & 18.71 & .21 & .73 & $.53^{* *}$ \\
\hline EFL learners' ability to produce the English target phonemes & 29.95 & .21 & .49 & $.24^{* *}$ \\
\hline
\end{tabular}

Note: ${ }^{*} p<.05: * * p<.01$.

As shown in Table 4, QDPR learning model might contribute significantly to EFL learners' knowledge of English target phonemes, $R^{2}=.53$ at $p<.01$. It means that QDPR learning model can account for $53 \%$ of the variation in EFL learners' knowledge of English target phonemes and 47\% of the variation might be explained by factors other than QDPR learning model. At the same time, QDPR learning model may also predict EFL learners' ability to produce the English target phonemes, $R^{2}=.24$ at $p<.01$. This implies that QDPR learning model can account directly for $24 \%$ of the variation in EFL learners' ability to produce the English target phonemes and $76 \%$ of the variation might be explained by factors other than those factors. 


\section{Discussion}

As indicated in the section of Introduction, there are four research questions proposed in the present study. The first two research questions are related to the effectiveness of QDPR learning model in improving EFL learners' knowledge of English pronunciation and their ability to pronounce the investigated English phonemes. Meanwhile, the last two research questions deal with the contribution of QDPR learning model to EFL learners' knowledge of the investigated English phonemes and their ability to produce them. The investigated English phonemes chosen in the present study were those categorized by Moedjito and Ito (2008) as common and serious mispronunciations.

The results of data analyses have led to an empirical evidence that QDPR learning model was significantly effective in improving both EFL learners' knowledge of the investigated English phonemes and their ability to pronounce them. The finding is consistent with Moedjito's (2013) findings which indicated that Test-Demonstration-Practice-Revision (TDPR) has a significant effect on EFL learners' ability to pronounce English vowels and consonants. The effectiveness of QDPR learning model in pronunciation teaching is also supported by the results of the analyses for the last two research questions. QDPR learning model might also contribute significantly to the improvement of EFL learners' knowledge and their ability to pronounce the investigated English phonemes.

Not only did Moedjito and Ito (2008) provide us the category of mispronunciations, but also they explained two main reasons for these common and serious mispronunciations, namely (1) the absence of English phoneme in EFL learners' mother tongue, and (2) different categorization of the same sounds in English and EFL learners' mother tongue. For example, the student participants have difficulty in differentiating $/ \mathrm{f} / \mathrm{from} / \mathrm{v} / \mathrm{because}$ both English phonemes do not exist in their mother tongue, Bahasa Sasak (the language used in Lombok Island of Nusa Tenggara Barat Province). Most of them say /p/ for the English /f/ and /v/. But, when the children of the island are growing up, they start learning to recite the Holy Quran. In this way, they have started learning the phoneme /f/. However, for some cases, most of them have got confused about the phonemes $/ \mathrm{f} / \mathrm{and} / \mathrm{p} /$. In many cases, the serious mispronunciations described by Moedjito and Ito (2008) often occur. When they want to say five, they say /parp/. But, when they want to say pipe, they say /farf/. It is much more complicated when they want to say five pipes, they will say /parp farfs/. Another example is when the student participants were required to say /ritt/ for reach and /ritg/ for rich. It is also difficult for them to differentiate both phonemes. This happens because these different English phonemes are not significantly different in their first language; they are the allophones of the phoneme $/ \mathrm{i} /$.

To reduce the problems, QDPR learning model is proposed to be an alternative learning model in pronunciation teaching in EFL classrooms. By implementing QDPR learning model as the main activity, teachers can identify students' difficulty in pronouncing English phonemes at the first step of their instruction. Teachers just give a quiz (for Q of QDPR), they can identify whether their students have problems with the target English phoneme or not. Based on the identification of the problems, teachers can provide an easy and clear explanation (because they use students' mother tongue) to students on how to produce the sounds, and in turn students are motivated to produce the target sounds by imitating teachers' demonstration (for D of QDPR). In this case, we think that phoneme imitation is important for students, but teachers' explanation in students' first language of how to produce the phoneme must be much more essential. Whenever students have understood the process of phoneme production, the learning activity can be continued to the next step, namely practice (for P of QDPR). In this step, students are given more chances to explore the sound-spelling relationship and to do more practices orally. Finally, wherever teachers find students' difficulty after practicing, they can go to revision (for R of QDPR). At this step, teachers can revise students' mispronunciations individually, in group, or classically.

\section{Conclusion}

Although our study has revealed several interesting findings about the implementation of Quiz-DemonstrationPractice-Revision (QDPR) learning model in pronunciation teaching in EFL classrooms, we must admit that the study has also several limitations. First, the data analysis was only based on the quantitative data which need to be confirmed with observations and in-depth interviews. Secondly, the target English phonemes were limited to common and serious mispronunciations faced by one group of participants who have the same linguistic background (in this case, those who speak Bahasa Sasak). Thirdly, we need more comprehensive raw data, particularly related to EFL learners' oral performance.

In spite of these limitations, several interesting results are disclosed. The current study aimed at investigating the effectiveness of Quiz-Demonstration-Practice-Revision (QDPR) as an alternative learning model in pronunciation teaching in EFL classrooms. The result of the study has revealed that there was a significant 
difference in the mean score of participants' scores before and after the treatment. This implies that QDPR may become an effective learning model for improving EFL learners' knowledge and their ability to pronounce the

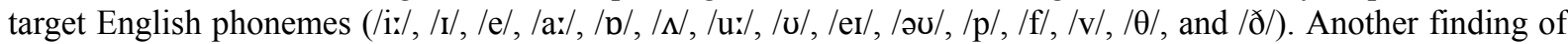
the study has discovered that QDPR might contribute significantly to the improvement of EFL learners' knowledge and ability to pronounce the investigated English phonemes. These empirical data suggest that QDPR may become an alternative model in pronunciation teaching.

We admit that the instruments used in the study have much to be improved but we believe that the findings of the study will serve as the point of reference for the teaching of pronunciation of English as a global language. Concerning the limitations mentioned above, we need to replicate the experiment with different type of EFL learners (for example, secondary school students as the student participants) and for a variety of tasks.

\section{References}

Abercrombie, D. (1963). Problems and principles in language study (2nd ed.). London: Longmans, Green and Co. Ltd.

Bowen, J. D., Madsen, H., \& Hilferty, A. (1985). TESOL techniques and procedures. Cambridge: Newbury House Publishers.

Celce-Murcia, M., Brinton, D. M., \& Goodwin, J. M. (1996). Teaching pronunciation: A reference for teachers of English to speakers of other languages. Cambridge: Cam-bridge University Press.

Cruttenden, A. (2001). Gimson's pronunciation of English (6th ed.). London: Arnold Publisher.

Crystal, D. (1997). English as a global language. Cambridge: Cambridge University Press.

Dalton, C., \& Seidlhofer, B. (1994). Pronunciation. Oxford: Ox-ford University Press.

Florez, M. C. (1998). Improving adult ESL learners' pronunciation skills. Digests. Retrieved March 3, 2015, from http://www.cal.org/caela/eslresources/digests/Pronun.html

Jenkins, J. (2000). The phonology of English as an international language. Oxford: Oxford University Press.

Jenner, B. (1989). Teaching pronunciation: The common core. Speak Out! 4, 2-4.

Kelly, G. (2000). How to teach pronunciation. England: Long-man, Ltd.

McKay, S. L. (2002). Teaching English as an international language. Oxford: Oxford University Press.

Moedjito. (2006). A study on perceptions of pronunciation among Indonesian EFL teachers and students. Unpublished master's thesis, Naruto University of Education, Naruto, Tokushima, Japan.

Moedjito. (2008). A search for factors determining global intelligibility of EFL learners' oral communication. Annual Review of English Language Education in Japan (ARELE) 19, 51-60.

Moedjito. (2016). The teaching of English Pronunciation: Perceptions of Indonesian school teachers and university students. English Language Teaching, 9(6), 1-12. https://doi.org/10.5539/elt.v9n6p30

Moedjito. English pronunciation practice. Selong: Hamzanwadi University Press (In press).

Moedjito \& Ito, H. (2008). Perceptions of the seriousness of mispronunciations of English speech sounds. Teaching English as a Foreign Language in Indonesia (TEFLIN) Journal 19(1), 70-91.

von Schon, C. V. (1987). The question of pronunciation. English Teaching Forum 25(4), 22-27.

Tudor, I. (2001). The dynamics of the language classroom. Cambridge: Cambridge University Press.

Walker, R. (2001). Pronunciation for international intelligibility. English Teaching Professional, 21. Retrieved May 24, 2005, from http://www3.telus.net/linguisticsissues/internationallyintelligibility.html

Wong, R. (1987). Teaching pronunciation: Focus on English rhythm and intonation. Englewood Cliffs, NJ: Prentice-Hall Regents. 


\section{Appendix A}

\section{Test of Oral Performance \\ Time: Approximately 10 minutes}

In this section of the test, you will have an opportunity to demonstrate your ability to pronounce English vowels and consonants.

Directions: Read the following passage at a normal speed, don't read too fast nor slowly. Although your utterance will be recorded, please feel relaxed. You are given five minutes to read it before recording. Please tell our staff if you are ready.

\section{What causes the seasons?}

It's all about Earth's tilt! Many people believe that Earth is closer to the sun in the summer and that is why it is hotter. And, likewise, they think Earth is farthest from the sun in the winter. Although this idea makes sense, it is incorrect.

It is true that Earth's orbit is not a perfect circle. It is a bit lop-sided. During part of the year, Earth is closer to the sun than at other times. However, in the Northern Hemisphere, we are having winter when Earth is closest to the sun and summer when it is farthest away! Compared with how far away the sun is, this change in Earth's distance throughout the year does not make much difference to our weather.

There is a different reason for Earth's seasons. Earth's axis is an imaginary pole going right through the centre of Earth from "top" to "bottom." Earth spins around this pole, making one complete turn each day. That is why we have day and night, and why every part of Earth's surface gets some of each. Earth has seasons because its axis doesn't stand up straight.

But what caused Earth to tilt? Long, long ago, when Earth was young, it is thought that something big hit Earth and knocked it off-kilter. So instead of rotating with its axis straight up and down, it leans over a bit. Cartoon of large object hitting Earth, knocking out big chunks of material that become the future Moon, and tilting the Earth's axis.

By the way, that big thing that hit Earth is called Theia. It also blasted a big hole in the surface. That big hit sent a huge amount of dust and rubble into orbit. Most scientists think that rubble, in time, became our Moon.By the way, that big thing that hit Earth is called Theia. It also blasted a big hole in the surface. That big hit sent a huge amount of dust and rubble into orbit. Most scientists think that rubble, in time, became our Moon.

As Earth orbits the sun, its tilted axis always points in the same direction. So, throughout the year, different parts of Earth get the sun's direct rays. Sometimes it is the North Pole tilting toward the sun (around June) and sometimes it is the South Pole tilting toward the sun (around December). It is summer in June in the Northern Hemisphere because the sun's rays hit that part of Earth more directly than at any other time of the year. It is winter in December in the Northern Hemisphere, because that is when it is the South Pole's turn to be tilted toward the sun. 


\section{Appendix B}

\section{Test of Pronunciation Knowledge \\ Time: Approximately 40 minutes \\ 100 Questions}

In this section of the test, you will have an opportunity to demonstrate your knowledge of English pronunciation, particularly segmental features (vowels and consonants) and their representing spelling.

Directions: Read the following groups of English words. Write 1 (One) in the brackets if all the underlined characters have the same sounds and write $\mathbf{0}$ (Zero) in the brackets if the sounds of the underlined characters are different. See the following examples.

\begin{tabular}{|c|c|c|c|c|c|c|c|c|c|}
\hline (1) ball & chat & jack & sack & $(0)$ & (2) bit & did & hit & ship & \\
\hline 01. father & brother & although & there & ( & 21. morale & branch & bath & a ftter & ( \\
\hline 02. swan & quality & watch & wa & ( & 22. echo & fold & pose & so & ( \\
\hline 03. complete & be & these & êdge & ( & 23. farthest & other & with & northern & ( \\
\hline 04. winter & over & filter & player & ( & 24. knowledge & cow & now & bow & ( \\
\hline 05. south & group & soup & through & ( & 25. believe & piece & field & siege & ( \\
\hline 06. of & canvas & vice & seryice & ( & 26. lemon & reason & abandon & soda & ( \\
\hline 07. paint & fire & fine & faint & ( & 27. chew & dew & flew & threw & ( \\
\hline 08. heart & $\underline{\underline{\text { ear }}}$ & pearl & clear & ( & 28. active & glove & wave & save & ( \\
\hline 09. outbreak & hour & loud & scout & ( & 29. cough & enough & laugh & though & ( \\
\hline 10. thumb & $\underline{\underline{\text { thick }}}$ & ether & $\underline{\underline{\text { thigh }}}$ & ( & 30. bite & $c \operatorname{limb}$ & design & item & ( \\
\hline 11. fast & past & fry & frost & ( & 31. country & young & trouble & southern & ( \\
\hline 12. thought & thing & south & weather & ( & 32. equal & even & email & êcology & ( \\
\hline 13. lodge & solve & doll & note & ( & 33. method & theorem & worthless & breather & ( \\
\hline 14. machine & police & prestige & suite & ( & 34. earth & $\underline{\underline{\text { through }}}$ & north & $\underline{\underline{\text { think }}}$ & ( \\
\hline 15. soda & sofa & zebra & amaze & ( & 35. pot & stock & $\mathrm{cos} t$ & chock & ( \\
\hline 16. foed & pool & book & shoet & ( & 36. tea & reason & season & swear & ( \\
\hline 17. nephew & phonetics & physics & graph & ( & 37. buffalo & affect & among & $\underline{\text { account }}$ & ( \\
\hline 18. peach & reach & leak & meatball & ( & 38. arrange & strange & danger & parent & ( \\
\hline 19. fill & pill & pray & supper & ( & 39. buttcher & cusshion & suggar & cultter & ( \\
\hline 20. put & shut & punish & cut & ( & 40. university & umpire & ulltimate & $\underline{\underline{\underline{u}}}$ tterance & ( \\
\hline
\end{tabular}

\section{Copyrights}

Copyright for this article is retained by the author(s), with first publication rights granted to the journal.

This is an open-access article distributed under the terms and conditions of the Creative Commons Attribution license (http://creativecommons.org/licenses/by/4.0/). 